\title{
Geostatistical modeling of "lethal coconut palm crown atrophy", a new disease in the State of Pará
}

\section{Modelagem geoestatística da "Atrofia Letal da Coroa Coqueiro", uma nova doença no Estado do Pará}

\author{
Adriano da Silva Gama ${ }^{1 *}$; Paulo Roberto Silva Farias²
}

\section{Highlights}

There is a concentration on the spatiotemporal distribution of ALCC disease.

The LCCA distribution was estimated through geostatistics.

LCCA forms aggregation patches of diseased plants.

\section{Abstract}

'Lethal Coconut Palm Crown Atrophy' (LCCA) is a rapidly spreading disease in Brazil, capable of quickly killing coconut trees and threatening the commercial exploration of this plant. The objective of this work was to characterize the spatial and temporal distribution pattern of LCCA in green dwarf coconut commercial plantation areas, located the municipality of Santa Izabel, mesoregion of Northeastern Pará, Brazil. Surveys were carried out at monthly intervals between January 2014 and December 2018, checking for plants with LCCA-characteristic symptoms. Geostatistics was applied to perform spatial-temporal disease estimates based on semivariogram modeling and preparation of ordinary kriging maps. These spatial estimates are conducted through interpolations that characterize data variability in the area. The spherical model yielded the best fit to the spatial distribution of the disease, as it presented the best coefficient of determination $\left(R^{2}\right)$, with the range varying between $14 \mathrm{~m}$ and $45 \mathrm{~m}$. The Spatial Dependence Index (SDI) was moderate in the evaluations carried out between 2014 and 2017 (in the 0.26-0.64 range), but not in 2018, when it was strong (0.23). The values of the clustering intensity of LCCA-symptomatic plants were estimated in nonsampled points. The spherical fit model of the data indicates an aggregated distribution pattern, shown by aggregation patches in the plantation, graded by values of dissemination intensity. The kriging maps allowed the observation that the disease expands between plants in the same line, suggesting the possibility of the presence of a short-range vector.

Key words: Cocos nucifera L. LCCA. Interpolation. Ordinary kriging.

\section{Resumo}

A 'Atrofia Letal da Coroa do Coqueiro' (ALCC) é uma doença de rápida disseminação no Brasil, capaz de matar os coqueiros rapidamente e ameaçar a exploração comercial da planta. O objetivo deste trabalho

1 Student of the Doctoral Course in the Agronomy Postgraduate Program, PGAGRO, Universidade Federal Rural da Amazônia, UFRA, Belém, PA, Brazil. E-mail: adriano.gama@ufra.edu.br

2 Prof. Dr., Institute of Agrarian Sciences, UFRA, Belém, PA, Brazil. E-mail: paulo.farias@ufra.edu.br

* Author for correspondence

Received: Mar. 11, 2021 - Approved: Sept. 15, 2021 
foi caracterizar o padrão de distribuição espacial e temporal de ALCC em áreas de plantio comercial de coco anão verde, localizadas no município de Santa Izabel, mesorregião do Nordeste do Pará, Brasil. As pesquisas foram realizadas em intervalos mensais entre janeiro de 2014 e dezembro de 2018, verificando se havia plantas com sintomas característicos da ALCC. A geoestatística foi aplicada para realizar estimativas espaço-temporais de doenças com base na modelagem de semivariogramas e na preparação de mapas de krigagem comuns. Essas estimativas espaciais são realizadas por meio de interpolações que caracterizam a variabilidade dos dados na área. O modelo esférico apresentou o melhor ajuste à distribuição espacial da doença, pois apresentou o melhor coeficiente de determinação $\left(R^{2}\right)$, com amplitude variando entre $14 \mathrm{~m}$ e 45m. O Índice de Dependência Espacial (SDI) foi moderado nas avaliações realizadas entre 2014 e 2017 (na faixa de $0,26-0,64)$, mas não em 2018 , quando era forte $(0,23)$. Os valores da intensidade de agrupamento de plantas sintomáticas ALCC foram estimados em pontos não amostrados. O modelo de ajuste esférico dos dados indica um padrão de distribuição agregado, mostrado por manchas de agregação na plantação, graduadas por valores de intensidade de disseminação. Os mapas de krigagem permitiram observar que a doença se expande entre plantas na mesma linha, sugerindo a possibilidade da presença de um vetor de curto alcance.

Palavras-chave: Cocos nucifera L. ALCC. Interpolação. Krigagem ordinária.

\section{Introduction}

The coconut tree (Cocos nucifera L.) is commercially explored in twelve million hectares in 90 countries, generating benefits for more than 80 million people (Ferraz, Assis, Coelho, Santiago, \& Santos, 2020). This palm species has great economic and social importance in producing countries (Harries \& Clement, 2014). The most recent data available on coconut production worldwide (from 2019) shows that 62.4 million tons of fruit were produced, mainly by Indonesia (30.1\%), Philippines (24.7\%) and India (19.0\%), which account for $73.8 \%$ of the total (United States Department of Agriculture [USDA], 2020).

Brazil is the fifth largest coconut producer in the world, with a $4.5 \%$ share of the worldwide production. According to Brazilian agribusiness statistics, the export of the fruit generated revenues of more than US $\$ 996,000$ in 2020 (Ministério da Agricultura Pecuária e Abastecimento [MAPA], 2021).
The State of Pará ranks third within Brazil with 17,311 hectares of planted area, yielding 175,215 tons of coconut, trailing only the States of Bahia and Ceará (Instituto Brasileiro de Geografia e Estatística [IBGE], 2019).

Pest attacks and diseases greatly damage coconut cultivation (Ferreira, Warwick, \& Siqueira, 2018). Currently, several phytosanitary problems affect coconut trees in the world (including Brazil): Lethal Yellowing (phytoplasmas of the 16Sr DNA IV group), Resinosis (Thielaviopsis paradoxa), Red palm mite (Raoiella indica Hirs), Red ring disease (Bursaphelenchus cocophilus), Coconut mite (Aceria guerreronis Keifer), among others (Barroso et al., 2019; Bonnot, Franqueville, \& Lourença, 2010; Carvalho et al., 2021; (Rezende, Melo, Oliveira, \& Gondim, 2016; Silva et al., 2016).

In Brazil, a disease called "Lethal Coconut Palm Crown Atrophy" (LCCA) was registered in 2012 in the State of Pernambuco. 
This disease affects the productivity of coconut trees with subsequent plant death and it can be found in several Brazilian states: Bahia, Amazonas, Sergipe, Roraima, Paraíba, and Pará (Ferraz et al., 2020).

LCCA symptoms differ from those characteristic of phytoplasma-induced diseases such as "lethal yellowing" (Gurr et al., 2016). However, there is similarity in symptoms between LCCA and another disease known as "Porroca" (short leaf), which spreads from Colombia towards Panama (Gilbert \& Parker, 2008).

In this context, despite the knowledge about the negative effect of LCCA on plantations, there are no confirmed studies on its etiology or epidemiology in coconut trees, nor on possible disease-transmitting vectors. Literature on the characterization of LCCA spatial and temporal distribution patterns is non-existent.

In this case, geostatistics is an adequate tool to identify spatial and temporal distribution patterns, helping to identify sources of contagion (Bonnot et. al., 2010). A variety of studies on spatial distribution modeling, such as Oliveira, Farias, Silva, Rodrigo and Araújo (2016), Rojo and PérezBadia (2015), Trindade, Fernades, Oliveira and Martins (2017) and Brandão, Dionísio, Farias, Schwartz and Carvalho (2018), employed geostatistics to characterize spatial distribution patterns, supporting pest identification and management strategies in various cultures. Therefore, the generation of spatial and temporal distribution maps helps in pest identification, management, and control methods, increasing their effectiveness (Duarte, Calvo, Borges, \& Scatoni, 2015).
Thus, due to the importance of this disease for the Brazilian coconut culture and the lack of basic studies to identify and implement adequate management strategies, the objective of this work was to apply geostatistical analysis to characterize the spatial and temporal distribution pattern of the Lethal Coconut Palm Crown Atrophy disease in coconut trees in the state of Pará.

\section{Materials and Methods}

\section{Experimental area}

The study was carried out in a commercial coconut plantation, located in the municipality of Santa Izabel - PA, belonging to the Reunidas Sococo farm (010 13' 40.16" S; $48^{\circ} 02^{\prime} 54.35^{\prime \prime} \mathrm{W}$ ). The soil in the area is predominantly dystrophic Quartzarenic Neosol: low particle aggregation capacity, very sandy, limited available water storage capacity, low clay and organic matter contents, rendering it susceptible to erosion (Teixeira, Donagemma, Fontana, \& Teixeira, 2017).

The region is characterized by high rainfall, with values of up to $3,000 \mathrm{~mm}$ and average relative humidity of approximately 80\% (Dubreuil, Fante, Planchon, \& Sant'anna, 2018). The climate classification according to Köppen-Geiger scale is of the Afi type, with the rainy season occuring between January and May and the dry season between June and December (Secretária do Estado e Meio Ambiente e Sustentabilidade [SEMAS], 2019).

\section{Experimental design}

The coconut variety analyzed in the study is the Brazilian green dwarf (Cocos 
nucifera L.), intended for water extraction, equilateral spacing $(7.5 \times 7.5 \times 7.5 \mathrm{~m}), 205$ plants/hectare, implemented between the years 2011/2012. The study data were obtained from the block named $\mathrm{H}$, containing four plots $(\mathrm{H} 121 ; \mathrm{H} 122 ; \mathrm{H} 123 ; \mathrm{H} 124)$, totaling 15,880 plants over 81.35 hectares. Three of the plots measured $250 \times 1000 \mathrm{~m}$, whereas a smaller one (H 121) measured $125 \times 1000 \mathrm{~m}$. Each plot has 155 rows of 33 plants, with the exception of plot $\mathrm{H} 121$, with only 17 plants per row (Figure 1).

\section{Database}

Data refer to the years 2014/2018, obtained by monitoring LCCA symptoms under field conditions. Symptomatic plants in the plots were registered in a temporal database (annual), made available by the company Sococo S/A, totaling 15,880 plants. The plants were inspected by trained field monitors, noting the presence or absence of symptoms by assigning the number one (1) or zero (0), respectively. Symptoms were identified using a diagrammatic scale available in the literature (Warwick, Talamini, Ferreira, \& Moreira, 2019). Field productivity data were provided by the company Sococo S/A. In measuring the productivity of the plots, agricultural model 'big bag' bags $(120 \times 90 \times 90 \mathrm{~cm})$ are used, made of polypropylene, which hold up to 400 units of fruit, which are collected by transshipment trucks; productivity is measured as bags/field.

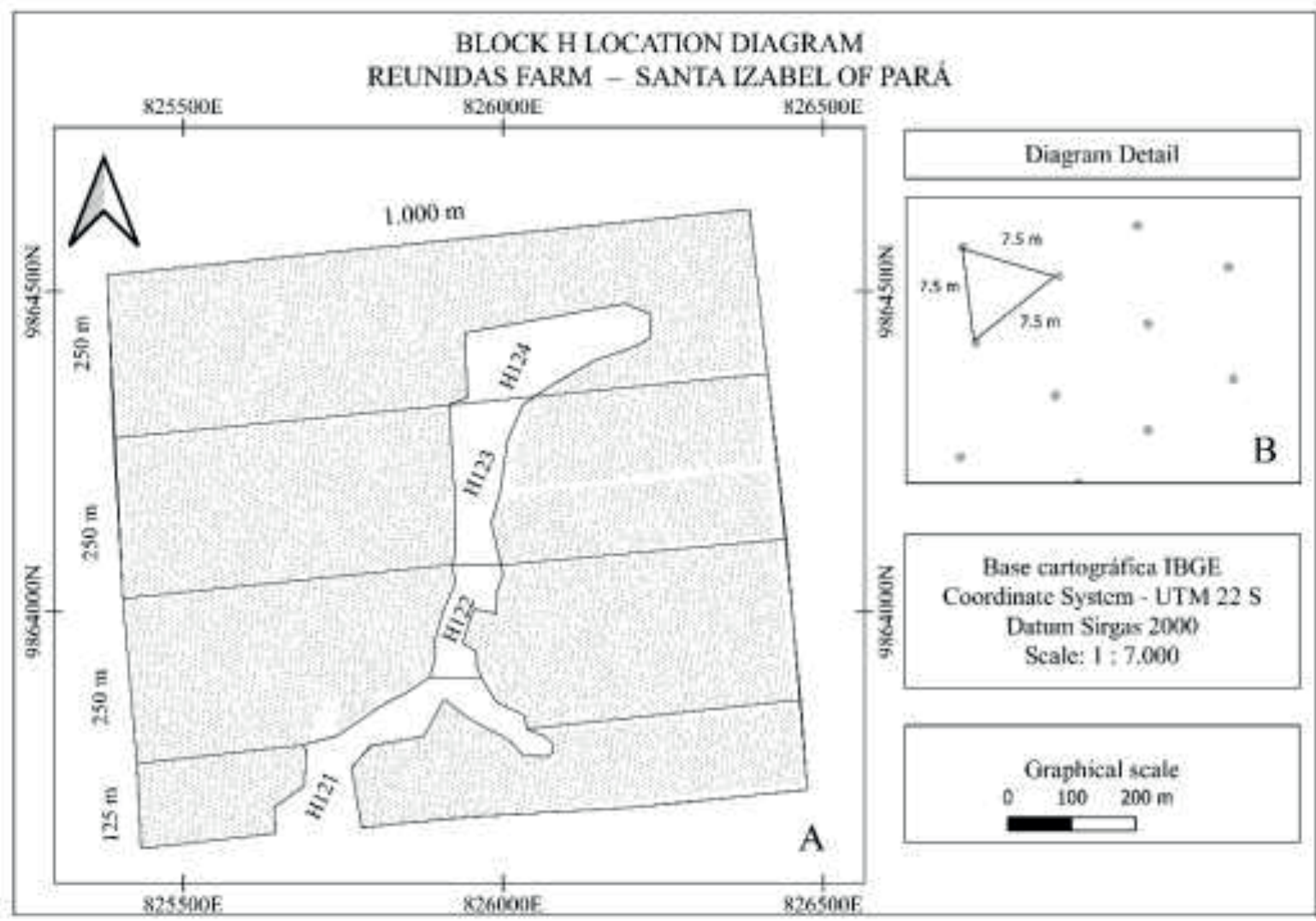

Figure 1. Arrangement of plots (A) and plants (B) in commercial plantation of Brazilian green dwarf coconut, Santa Izabel, Pará, Brazil. 


\section{Geostatistics}

The methodology of Vieira, Hatfield, Nielsen and Biggar (1983) was followed using the information on the position of the sample $(\mathrm{x}, \mathrm{y})$ and the value that the variable symptoms (0 or 1) assumed at each point (plant). Thus, from each sampling point, the value of the study variable and the coordinates (longitude and latitude) of the point where the sampling was performed were obtained.

\section{Experimental semivariogram}

The semivariogram expresses the spatial variability between the samples, being a vector-dependent function (h), i.e., the distance between sample pairs. It is able to measure the degree of dissimilarity between pairs due to the distance and orientation between two sampling sites (Seidel \& Oliveira, 2014). It is an essential procedure in geostatistical analysis, as the chosen model will be used in ordinary kriging for data interpolation. The semivariogram is estimated by:

$$
\gamma *(h)=\frac{1}{2 N(h)} \sum_{i=1}^{N(h)}[Z(x i)-Z(x i+h)]^{2}
$$

Where, $\gamma(\mathrm{h})$ is the semi-variance calculated by the distance $\mathrm{h} ; \mathrm{N}(\mathrm{h})$ is the total number of diseased plants analyzed, separated by a distance (h). In the case of space-dependent variables, the values $\left[Z\left(x_{i}\right)-Z\left(x_{i}+h\right)\right]^{2}$, increase until reaching the stability plateau, where the distance $(\mathrm{h})$ between the pairs no longer interferes with the present variability (Yamamoto \& Landim, 2013).

Semivariance measures the degree of spatial dependence between samples, assuming stationarity in diseased plant propagation. This means that the semivariogram measures the variability conditioned by the distance (h) between samples. This means that observations closer to one another tend to behave more similarly than those separated by greater distances (Nanos, Calama, Montero, \& Gil, 2004).

\section{Spherical model}

The semivariogram model used in this work was the spherical one, as it yielded the best coefficient of determination $\left(R^{2}\right)$. The spherical model has a linear behavior close to the origin that represents continuous but nondifferentiable phenomena, being one of the most used mathematical models (Yamamoto \& Landim, 2013). The spherical model is represented by the following equation:

$$
\begin{gathered}
\gamma *(h)=C_{0}+C_{1}\left[1.5 \frac{h}{a}-0.5\left(\frac{h}{a}\right)^{3}\right], \text { for } 0<h<a \\
\gamma *(h)=C_{0}+C_{1}, \quad \text { for } h \geq a
\end{gathered}
$$

Where, $\mathrm{C}_{0}$ is the nugget effect, $\mathrm{C}_{1}$ is the plateau after passing a straight line that intercepts the $y$ axis at $C_{1}$ and is tangent to the first points near $\mathrm{h}=0$. This tangent will cross the plateau at a distance, $a^{\prime}=2 / 3$ a. Thus, the range (a) will be $a=3 a^{\prime} / 2$. The spherical model is linear up to approximately $1 / 3$ a.

\section{Mapping}

The Surfer (v.11) software was used to interpolate data. It is a grid-based mapping program that interpolates irregularly spaced $X Y Z$ data into a regularly spaced grid, allowing the adjustment of interpolation and grid parameters, identifying the spatial continuity 
of the data with variograms modeled as a function of the degree of spatial dependence between samples (Golden Software, 2014). The semivariograms were adjusted based on the determination index $\left(\mathrm{R}^{2}\right)$, to choose the best model as a function of the mean square of the error, standard error of prediction, and the autocorrelation between the data (Seidel \& Oliveira, 2016; Silva et al., 2016).

\section{Kriging}

Based on the fitted semivariograms, ordinary kriging maps were constructed, which showed the spatial distribution of LCCA in plots, modeling the present variability structure. Moreover, spatial dependence indices $\left[S D I=C_{0} /\left(C_{0}+C_{1}\right)\right.$ ] were generated, classified according to intervals that consider spatial dependence into three types: strong (SDI < 0.25), moderate $(0.25<\mathrm{SDI}<0.75)$, and weak (SDI > 0.75) according to the work of Cambardella et al. (1994). The clustering intensity values of plants presenting LCCA symptoms were estimated in non-sampled points, using the following equation:

$$
Z^{*}\left(X_{0}\right)=\sum_{i=1}^{N} \lambda_{i} Z\left(x_{i}\right)
$$

Where, $Z$ * is the reference location estimate and $x_{i}$ are the linearly combined values of the neighboring samples. $\mathrm{N}$ symbolizes the related measured values of the estimate, $\lambda_{i}$ was the moderation associated with the measured values. In this method, the weights were calculated under two restrictions: minimum variance possible, and the estimator does not show a trend (Journel \& Huijbregts, 2003). The most suitable model for the parameters was selected through the standardization and adjustment of the data, estimated by:

$$
\gamma(h)=\left[C_{0}+C_{1} * \operatorname{model}(\alpha)\right]
$$

Where, $C_{0}=$ minimum semi-variance, $\left(C_{0}+C_{1}\right)$ $=$ maximum semi-variance, $\alpha=$ aggregation interval, and $h=$ distance that separates the obtained point pairs (Yamamoto \& Landim, 2013).

\section{Results and Discussion}

\section{Fruit productivity}

The productivity of harvested fruits was measured in 'bags' (400 fruits/bag) per plot. Plot productivity was strongly affected in 2014 and 2015, with 2016 being the year yielding the greatest reduction in fruit production - all plots produced less than 500 bags. Figure 2 shows the differences in productivity between each plot between 2014 and 2018. 


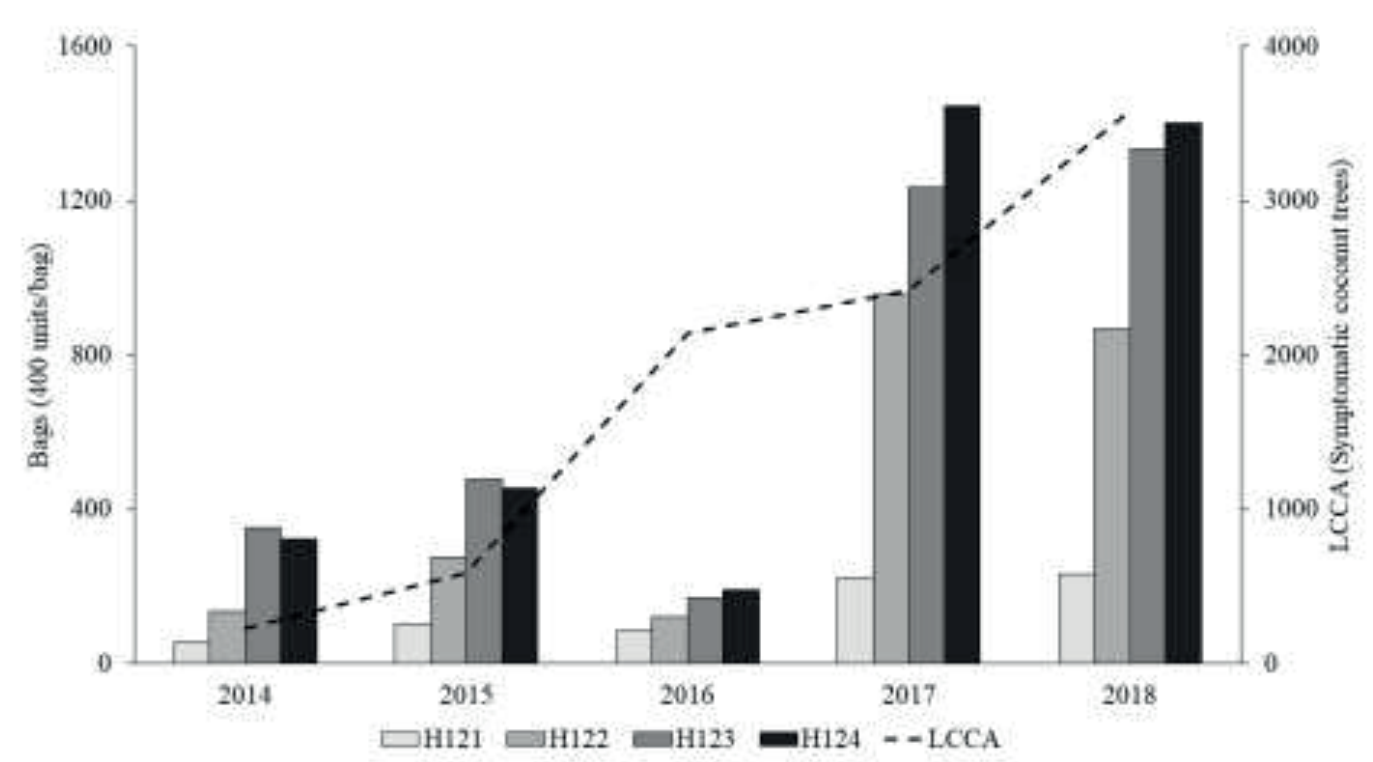

Figure 2. Coconut production (bags) and LCCA incidence (number of symptomatic coconut trees) between 2014 and 2018 in commercial plantation of Brazilian green dwarf coconut, Santa Izabel, Pará, Brazil.

\section{LCCA Symptomatology}

There is marked reduction of the crown from tissues in the apical growth region. This is followed by other symptoms such as shortening of the arrow leaflets (Figure 3A), complete leaf atrophy (Figure $3 \mathrm{~B})$, spathe shortening (Figure $3 \mathrm{C}$ ) and fruit abortion (Figure 3D). There are variations in the symptomatologic expression of LCCAaffected plants, and it can be associated with more than one disease present in the area, which hinders defining what the characteristic symptoms of the disease really are. The highest prevalence of symptomatic plants occurred in plots $\mathrm{H} 121$ and $\mathrm{H} 122$, as described above. This reflects the decrease in the number of new leaves, leaflet shortening, reduction in photosynthesis, early-stage fruit abortion, followed by plant death.

The improvement in bag productivity in 2017 and 2018 stemmed from the adoption of some management techniques such as reinforced fertilization and pest control, and the improvement in the rainfall index in the region. Although productivity improved, the number of LCCA-affected plants continued to grow across plots, with a higher incidence in $\mathrm{H} 121$ and $\mathrm{H} 122$ where there was a need to eliminate plants, causing a decrease in the number of bags, compared to the productivity standard of plots $\mathrm{H} 123$ and $\mathrm{H} 124$, where the number of bags remained above 800 . 

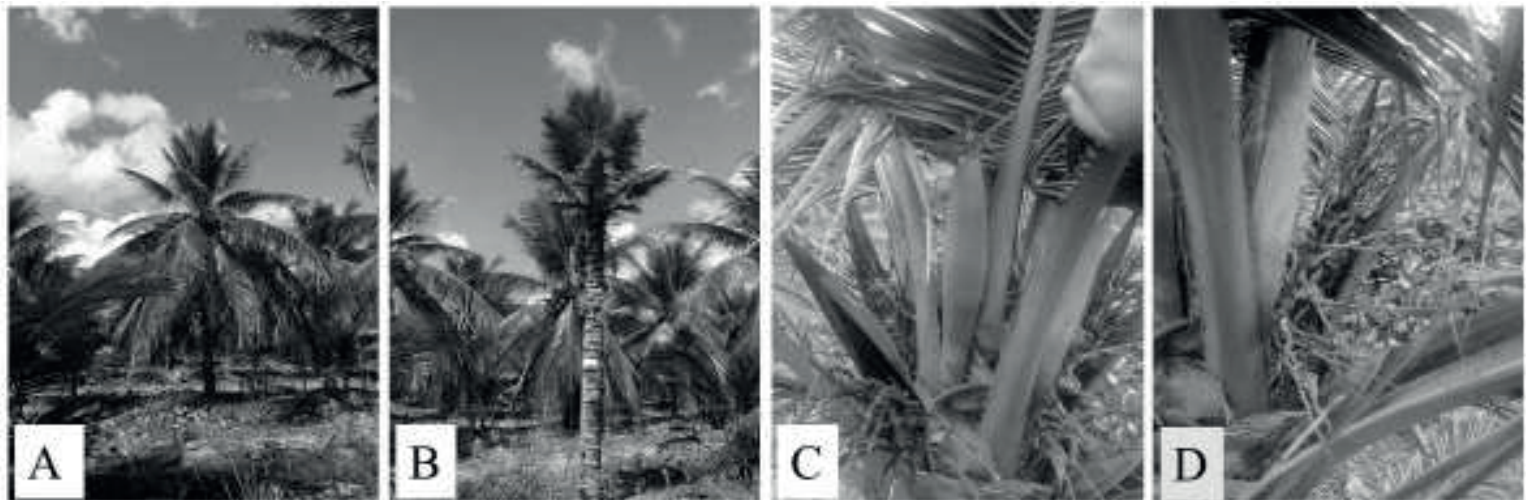

Figure 3. LCCA symptoms in several coconut organs. (A) shortening of the arrow leaflets, (B) complete atrophy, (C) spathe shortening and (D) fruit abortion in commercial plantation of Brazilian green dwarf coconut, Santa Izabel, Pará, Brazil.

Between 2014 and 2015 the number of LCCA-affected plants in plots varied between 40 and 365, with a cumulative value of 231 (2014) and 591 (2015) symptomatic plants, representing a considerable increase [from $1.45 \%$ to $3.72 \%$ ] compared to the initial value over just one year of symptom-monitoring. Subsequent surveys showed a significant growth in the number of diseased plants
- 13.51\% and $15.26 \%$ in 2016 and 2017, respectively. From 2016 to 2018, the plants in plots $\mathrm{H} 121$ and $\mathrm{H} 122$ exhibited the most symptoms; the spread of the disease reached a cumulative value of 3,587 (2018) symptomatic plants in the four plots in the last evaluation, which represented $22.59 \%$ of plants affected during the period analyzed (Figure 4).

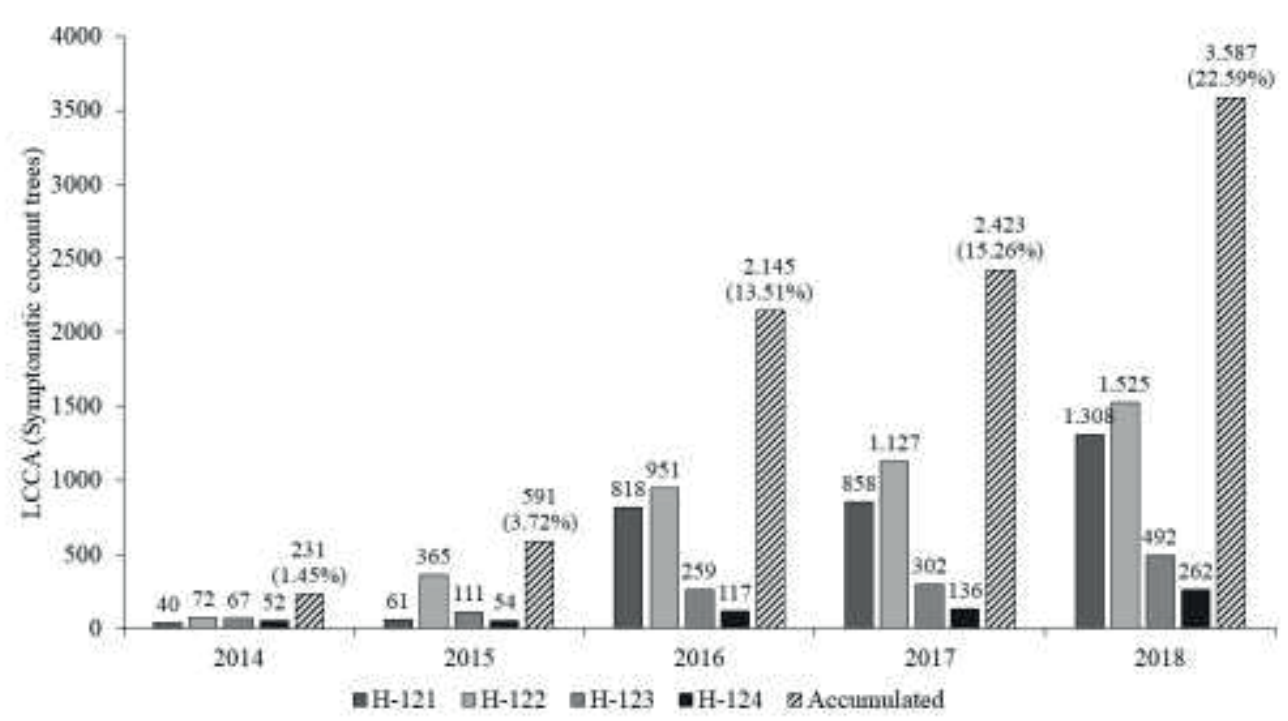

Figure 4. Percentage of LCCA incidence per plot and total experimental area (accumulated) between 2014 and 2018 in commercial plantation of Brazilian green dwarf coconut, in the municipality of Santa Izabel, Pará, Brazil. 


\section{Spatial dependence}

Geostatistics is considered an auxiliary qualitative research method, favoring a reduction in the relative inventory costs of planting issues, providing results that are more detailed and reliable than those obtained using classical statistics, which do not consider data position $(x, y)$ (Lundgren, Silva, \& Ferreira, 2015). Spatial dependence analysis enables the observation of the spatial dependence structure, which associates distances with semi-variances, helping the model's correction factor by the determination index $\left(R^{2}\right)$ (Seidel \& Oliveira, 2016).

The methodology used by Cambardella et al. (1994) stands out in defining the spatial dependence degree. This evaluation method uses the nugget effect and the $\left(C_{0}+C_{1}\right)$ contribution. On the other hand, the Spatial Dependence Index (SDI) methodology proposed by Seidel and Oliveira (2016) includes the range parameter and a model correction factor in the analysis. The SDI aims to consider the geometric aspects of the area, covering all spatial dependence characteristics.

The spatial dependence of the number of LCCA-symptomatic plants was assessed using semivariograms and the spherical model was the one that best fit the data, as it provided higher coefficient of determination $\left(R^{2}\right)$ values in all evaluated years, thus demonstrating that geostatistics can help monitor the spatial and temporal distribution of LCCA in the field. The coefficient of determination $\left(\mathrm{R}^{2}\right)$ indicates the quality of fit of the semivariogram model values close to 1.0 indicate a good fit. In the present work, $\mathrm{R}^{2}$ varied between 0.91 and 0.99. The parameters of the semivariograms used are described in table 1.

\section{Table 1}

Semivariogram parameters, range area, coefficient of determination, randomness index, experimental model for geostatistical analysis and spatial dependence index, in a Brazilian green dwarf coconut commercial plantation, municipality of Santa Izabel, Pará, Brazil

\begin{tabular}{|c|c|c|c|c|c|c|c|c|c|}
\hline \multirow{2}{*}{${ }^{1}$ Year } & \multirow{2}{*}{${ }^{2}$ Area $\left(m^{2}\right)$} & \multicolumn{8}{|c|}{ Parameters } \\
\hline & & ${ }^{3} \mathrm{C}_{0}$ & ${ }^{4} \mathrm{C}_{1}$ & ${ }^{5} a(m)$ & ${ }^{6} \mathrm{R}^{2}$ & ${ }^{7} \mathrm{k}$ & ${ }^{8}$ Model & 9SDI & ${ }^{10} \mathrm{NPF}$ \\
\hline 2014 & 3.630 & 0.017 & 0.0094 & 34 & 0.94 & 0.64 & Spherical & Moderate & 74 \\
\hline 2015 & 2.640 & 0.016 & 0.0035 & 29 & 0.99 & 0.31 & Spherical & Moderate & 54 \\
\hline 2016 & 615 & 0.016 & 0.045 & 14 & 0.91 & 0.26 & Spherical & Moderate & 12 \\
\hline 2017 & 706 & 0.019 & 0.043 & 15 & 0.91 & 0.30 & Spherical & Moderate & 14 \\
\hline 2018 & 6.358 & 0.006 & 0.019 & 45 & 0.99 & 0.23 & Spherical & Strong & 130 \\
\hline
\end{tabular}

${ }^{1}$ Sampling year; ${ }^{2}$ Estimated area by $\pi . r^{2}(r=a) ;{ }^{3}$ Nugget effect; ${ }^{4}$ Spatial variance; ${ }^{5}$ Range (meters); ${ }^{6} \mathrm{Coefficient}$ of determination; ${ }^{7} \mathrm{k}$ index for spatial randomness, estimated by the $C_{0} /\left(C_{0}+C_{1}\right)$ ratio; ${ }^{8}$ Model fit; ${ }^{9}$ Spatial Dependence; ${ }^{10}$ Number of diseased plants per focus. 
The parameter $\mathrm{k}$ estimates the degree of randomness in surveys; in our samplings $\mathrm{k}$ values ranged from 0.23 to 0.64 (Table 1), indicating a maximum variation of $64 \%$ in the LCCA surveys. These results fall within the recommendations by Journel and Huijbregts (2003), who mentioned that values greater than 0.80 indicate randomness and no dependence between samples. LCCA exhibits an aggregated dispersal pattern: the probability of a healthy plant to present the disease is higher when neighboring plants are sick. Generally, this pattern is strongly linked to the presence of a vector, which transmits the disease over short distances, preferably within the planting line (Bassanezi \& Laranjeira, 2007). This pattern is also observed by other authors who have studied the behavior of agricultural pests and who have shown that vector-infected plants have an effect on neighboring plants (Correia et al., 2019; Oliveira et al., 2016).

The aggregated distribution model is the one that best suits the spatial behavior of the disease, as it shows the foci of incidence in the form of concentric areas that tend to expand in all directions according to the disease's population growth (Bastos et al., 2019). Studies by Silva et al. (2016), found an aggregate distribution with moderate spatial dependence for the red ring disease (caused by Bursaphelenchus cocophilus) and strong spatial dependence for resinosis incidence (caused by Thielaviopsis paradoxa), diseases that affect coconut trees in the study region.

There was a decrease in the aggregation radius in 2015, 2016 and 2017 compared to the first year of evaluation
(2014), reducing the formation of clustered patches, which may have occurred due to the elimination of diseased plants, decreasing the number of disease incidence outbreaks; nevertheless, the aggregation radius increased again in 2018, when a new outbreak of diseased plants was also observed, with a maximum range of $45 \mathrm{~m}$ (Table 1). Fields $\mathrm{H} 121$ and $\mathrm{H} 122$ were the ones with the greatest disease progress throughout the period. Depending on the ranges, it was possible to determine the size of the areas $\left(\mathrm{m}^{2}\right)$ and the number of diseased plants per aggregation focus (NPF) (Table 1). This indicates that the range was able to project the area of influence with diseased plants; for instance, a minimum range distance of 14 meters implies that 12 plants are likely to show LCCA symptoms, and that a maximum range distance of 45 meters indicates at least 130 symptomatic plants, if there is an initial outbreak. These results help in defining monitoring strategies, as using spacings smaller than the ranges found allow obtaining an efficient way of sampling in specific areas. The kriging maps better show the evolution of the disease in the field through the formation of clustered patches and their respective semivariogram adjustment values for generating maps of the spatial and temporal distribution of the disease (Figure 5).

The thematic kriging maps show that infections were not distributed over the total surface area of the analyzed plots, with areas showing with a higher incidence of diseased plants, making it necessary to direct control measures to the specific areas of contagion. 

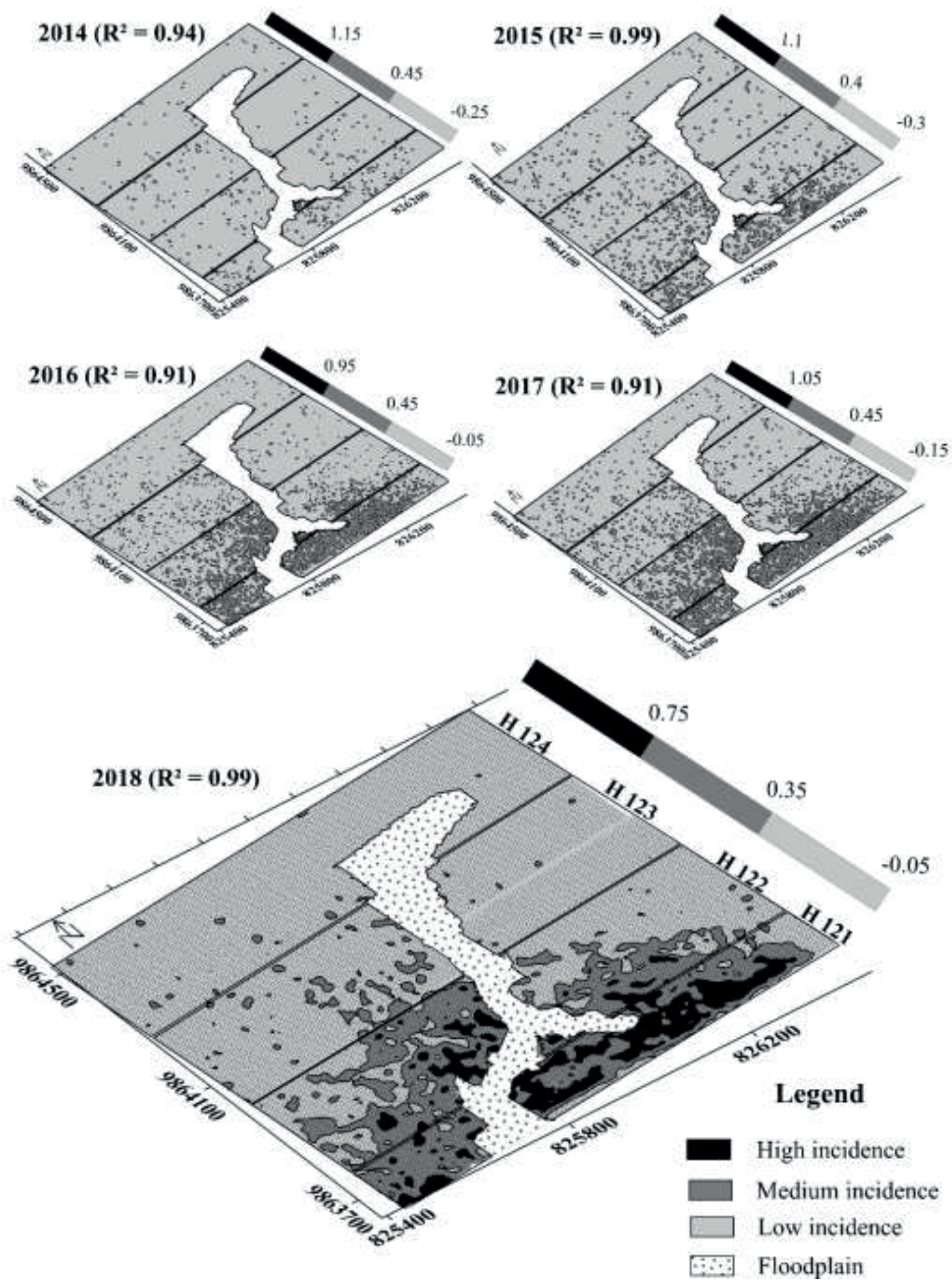

Figure 5. Kriging map of the spatial and temporal distribution of LCCA in a commercial Brazilian green dwarf coconut plantation, in the years 2014-2018. Santa Izabel municipality, Pará, Brazil. 


\section{Conclusion}

The spatial distribution of lethal coconut palm crown atrophy occurs in clusters with spatial dependence described by the spherical model, forming aggregation patches from 14 to $45 \mathrm{~m}$ (model range);

The spherical fit model of the data indicates an aggregated distribution pattern, shown through patches of aggregation in the plantation;

Kriging maps show that disease expansion occurs among plants nearby, suggesting the presence of a short-range vector, which requires further studies.

\section{Acknowledgments}

To the Superintendent of Sococo Agroindústria da Amazônia $S$ / $A$, to the technical team of plant health at the Reunidas Sococo farm for greatly contributing to the success of this research, to the Universidade Federal Rural da Amazônia (UFRA) and the Postgraduate Program in Agronomy (PPGAGRO), through the Postgraduate Support Program (PROAP - CAPES).

\section{References}

Barroso, G., Rocha, C. M., Moreira, G. F., Hata, F. T., Roggia, S., Ventura, M. U., Pasini, A., Silva, J. E. P., Holtz, A. M., \& Moraes, G. J. (2019). What is the Southern Limit of the Distribution of Red Palm Mite, Raoiella indica (Acari: Tenuipalpidae), in Agricultural Lands in Brazil? Florida Entomologist, 102(3), 581-85. doi: 10.16 $53 / 024.102 .0334$
Bassanezi, R. B., \& Laranjeira, F. F. (2007). Spatial patterns of leprosis and its mite vector in commercial citrus groves in Brazil. Plant Pathology, 56(1), 97-106. doi: 10.1111/j.1365-3059.2006.01457.x

Bastos, L. F., Santos, A. V. F., Penner, F. V., Siqueira, L. M. M., Silva, A. G., Martins, I. C. F., Lins, P. M. P., \& Batista, T. F. V. (2019). Spatial Analysis and Population Dynamics of Haplaxius crudus (Hemiptera: Cixiidae) in Coconut Amazon. Journal of Agricultural Science, 11(14), 186-197. doi: 10.5539/jas.v11n14p186

Bonnot, F., Franqueville, H., \& Lourença, E. (2010). Spatial and spatiotemporal pattern analysis of coconut lethal yellowing in Mozambique. Phytopathology, 100(4),300312. doi: 10.1094/PHYTO-100-4-0300

Brandão, A. D. S., Dionisio, L. F. S., Farias, P. R. S., Schwartz, G., \& Carvalho, J. O. P. (2018). Spatial distribution pattern of Euxylophora paraensis Huber in a natural managed forest in the Eastern Amazon. Revista Brasileira de Ciências Agrárias, 13(3), 1-9. doi: 10.5039/agraria.v13i3a5545

Cambardella, C. A., Moorman, T. B., Novak, J. M., Parkin, T. B., Karlen, D. L., Turco, R. F., \& Konopka, A. E. (1994). Field-scale variability of soil properties in central lowa soils. Soil Science Society of America Journal, 58(5), 1501-1511. doi: 10.2136/ sssaj1994.03615995005800050033x

Carvalho, L. L. B., Castro, H. S., Campos, I. L., Anhê, B. B., Jucá, A. C. C., Oliveira, D. A., Lins, P. M. P., Silva, G. B., \& Batista, T. F. V. (2021). Edaphic entomofauna associated with coconut crops in the eastern Amazon. Semina: Ciências Agrárias, 42(5), 2615-2628. doi: 10.5433/1679-03 $59.2021 v 42 n 5 p 2615$ 
Correia, R. G., Oliveira, F. A., Souza, L. S., Neves, R. L. P., Senado, J. A. V., Santos, J. T. S., \& Batista, T. F. V. (2019). Coleopterans prospection associated to forest ecosystems of Swietenia macrophylla (King), Eastern Amazonia. Semina: Ciências Agrárias, 40(5), 1775-1788. doi: 10.5433/1679-0359. 2019v40n5p1775

Duarte, F., Calvo, M. V., Borges, A., \& Scatoni, I. B. (2015). Geostatistics and Geographic Information Systems to Study the Spatial Distribution of Grapholita molesta (Busck) (Lepidoptera: Tortricidae) in Peach Fields. Neotropical Entomology, 44, 319-327. doi: 10.1007/s13744-015-0288-3

Dubreuil, V., Fante, K. P., Planchon, O., \& Sant'anna, J. L. Neto. (2018). Les types de climats annuels au Brésil: une application du classement de Köppen de 1961 à 2015. Confins. Revista Franco-Brasileira de Geografia, 37, 1-27. doi: 10.4000/ confins.15738

Ferraz, L. G. B., Assis, T. C., Coelho, I. L., Santiago, M. F., \& Santos, A. M. G. (2020). Nova doença ameaça coqueirais brasileiros. Pesquisa Agropecuária Pernambucana, 25(1), 4-8. doi: 10.12661/pap.2020.005

Ferreira, J. F. S., Warwick, D. R. N., \& Siqueira, L. A. (2018). A cultura do coqueiro no Brasil. (3a ed.). Brasília, DF: FUNEP.

Gilbert, G. S., \& Parker, I. M. (2008). Porroca: An emerging disease of coconut in Central America. Plant Disease, 92(5), 826-830. doi: 10.1094/PDIS-92-5-0826

Golden Software. (2014). Surfer 12 User 's Guide (No. 12; pp. 71). Retrieved from https://www. goldensoftware.com/

Gurr, G. M., Johnson, A. C., Ash, G. J., Wilson, B. A. L., Ero, M. M., Pilotti, C. A., Dewhurst, C. F., \& You, M. S. (2016). Coconut lethal yellowing diseases: A phytoplasma threat to palms of global economic and social significance. Frontiers in Plant Science, 7(1), 1-21. doi: 10.3389/fpls.2016.01521

Harries, H. C., \& Clement, C. R. (2014). Longdistance dispersal of the coconut palm by migration within the coral atoll ecosystem. Annals of Botany, 113(4), 565-570. doi: 10.1093/aob/mct293

Instituto Brasileiro de Geografia e Estatística [IBGE] (2019). Indicadores Produção Agrícola. Recuperado de https://sidra. ibge.gov.br/tabela/5457

Journel, A. G., \& Huijbregts, J. C. H. (2003). Mining geoestatistics. (2a ed.). Nova York: Blackburn Press Krame University of Virginia.

Lundgren, W. J. C., Silva, J. A. A., \& Ferreira, R. L. C. (2015). Estimação devolume de madeira de eucalipto por cokrigagem, krigagem e regressão. Cerne, 21(2), 243-250. doi: $10.1590 / 01047760201521021532$

Ministério da Agricultura Pecuária e Abastecimento [MAPA] (2021). Estatisticas de Comércio Exterior do Agronegócio Brasileiro. AGROSTAT. Recuperado de http://indicadores. agricultura.gov.br/agrostat/index.htm

Nanos, N., Calama, R., Montero, G., \& Gil, L. (2004). Geostatistical prediction of height/diameter models. Forest Ecology and Management, 195(1), 221-235. doi: 10.1016/j.foreco.2004.02.031

Oliveira, F. J., Farias, P. R. S., Silva, A. G., Rodrigo, K. C. V., \& Araújo, F. C. B. (2016). Distribuição espacial da leprose dos citros na Amazônia Oriental. Revista Ciência Agronômica, 47(1), 56-68. doi: 10. 5935/1806-6690.20160007 
Rezende, D., Melo, J. W. S., Oliveira, J. E. M., \& Gondim, M. G. C. (2016). Estimated crop loss due to coconut mite and financial analysis of controlling the pest using the acaricide abamectin. Experimental and Applied Acarology, 69(3), 297-310. doi: 10.1007/s10493-016-0039-0

Rojo, J., \& Pérez-Badia, R. (2015). Science of the Total Environment Spatiotemporal analysis of olive $\mathrm{fl}$ owering using geostatistical techniques. Science of the Total Environment, 505(1), 860-869. doi: 10. 1016/j.scitotenv.2014.10.022

Secretária do Estado e Meio Ambiente e Sustentabilidade [SEMAS] (2019). Classificação climática do Pará (Método de Koppen). Belém. Recuperado de https://www.semas.pa.gov.br/hidromet/

Seidel, E. J., \& Oliveira, M. S. (2014). New geostatistical index for measuring spatial dependence. Revista Brasileira de Ciência do Solo, 38(3), 699-705. doi: 10.1590/ S0100-06832014000300002

Seidel, E. J., \& Oliveira, M. S. (2016). A classification for a geostatistical index of spatial dependence. Revista Brasileira de Ciência Solo, 40(1), 1-10. doi: 10.15 90/18069657rbcs20160007

Silva, C. M., Macambira, L., Mercês, E., Silva, G. B., Lins, P. P., \& Carvalho, E. A. (2016). Distribuição espacial do anel vermelho (Bursaphelenchus cocophilus) e da resinose (Thielaviopsis paradoxa) em coqueiro. Revista Brasileira de Ciências Agrárias, 11(3), 192-197. doi: 10.5039/ agraria.v11i3a5385
Teixeira, P. C., Donagemma, G. K., Fontana, A., \& Teixeira, W. G. (2017). Manual de Métodos de Análise de Solo (3a ed.). Brasília. Recuperado de https://www.embrapa. br/busca-de-publicacoes/-/publicacao/ 1085209/manual-de-metodos-deanalise-de-solo

Trindade, R. B., Fernandes, M. G., Oliveira, A. C., \& Martins, P. H. A. (2017). Distribuição espacial de Spodoptera frugiperda (J. E. Smith) (Lepidoptera, noctuidae) em milho convencional e Bt. EntomoBrasilis, 10(2), 89-93. doi: 10.12741/ebrasilis.v10i2.683

United States Department of Agriculture [USDA] (2020). Foreign Agricultural Service. Production, Supply and Distribution (PSD) Datasets. Retrieved from https://apps.fas.usda.gov/psdonline/ app/index.html\#/ app/home

Vieira, R., Hatfield, J. L., Nielsen, D. R., \& Biggar, W. (1983). Geostatistical theory and application to variability of some agronomical properties. Hilgardia, 51(3), 1-75. doi: 10.3733/hilg.v51n03p075

Warwick, D. R. N., Talamini, V., Ferreira, J. F. S., \& Moreira, M. A. B. (2019). Escala diagramática para avaliação da severidade da Atrofia Letal da Coroa do Coqueiro (ALCC) (No. 221; Vol. 1). Sergipe, PE: EMBRAPA. Recuperado de https://www.embrapa.br/en/busca-depublicacoes/-/publicacao/11087 14/ escala-diagramatica-para-avaliacao-daseveridade-da-atrofia-letal-da-coroa-docoqueiro-alcc

Yamamoto, J. K., \& Landim, P. M. B. (2013). Geostatística: conceitos e aplicações. São Paulo, SP: Oficina de Textos. 